\title{
Antimicrobial Evaluation of Crude Methanolic Leaf Extracts from Selected Medicinal Plants Against Escherichia coli
}

\author{
Hibert Rachuonyo Opinde ${ }^{1^{*}}$, Gatheri $\mathbf{G W}^{2}$ and Nyamache $\mathbf{A K}^{1}$ \\ ${ }^{1}$ Department of Microbiology, Kenyatta University, Nairobi, Kenya \\ ${ }^{2}$ Department of Plant Sciences, Kenyatta University, Nairobi, Kenya
}

*Corresponding author: Hibert Rachuonyo Opinde, Department of Microbiology, Kenyatta University, P.O Box 43844-00100, Nairobi, Kenya, Tel:+254728128031; Email: hibertrachuonyo@gmail.com

Received date: March 22, 2016; Accepted date: April 28, 2016; Published date: May 03, 2016

Copyright: $\odot 2016$ Opinde HR, et al. This is an open-access article distributed under the terms of the Creative Commons Attribution License, which permits unrestricted use, distribution, and reproduction in any medium, provided the original author and source are credited.

\begin{abstract}
This study was aimed at determining the antibacterial effects of the selected plant leaf extracts of Tagetes minuta, Aloe secundiflora, Vernonia lasiopus and Bulbine frutescens against clinical isolate of Escherichia coli. The plants materials were obtained from Kenyatta University arboretum and identified by University taxonomist and voucher specimen deposited in the University. Methanol was used as the solvent for the extraction process and the antimicrobial activity test carried out using the disc diffusion method. All the plants extracts analysed had antimicrobial activity against Escherichia coli with Tagetes minuta extract being the most active at low concentrations $(8.7 \mathrm{mg} / \mathrm{ml})$. The standard antibiotic used for positive control was ciprofloxacin $(5 \mu \mathrm{g} / \mathrm{ml})$ while distilled water and dimethyl sulphoxide were used as negative control. Screening of phytochemical showed the presence of four phytochemicals; saponins, tannins, alkaloids and flavonoids.
\end{abstract}

Keywords: Disc diffusion method; Phytochemicals; Escherichia coli; Ciprofloxacin; Dimethyl sulphoxide

\section{Introduction}

Medicinal plants are used by almost $80 \%$ of the world's population for their basic health care because of their low cost and ease in availability [1]. Herbal drugs made from medicinal plants have been used from ancient times to treat various diseases and their antimicrobial properties make them a rich source of many potent drugs [2]. The use of herbal medicinal plants has always played a positive role in the control or prevention of diseases such as diabetes, heart disorders and various cancers [3]. The genus Tagetes belongs to the Asteraceae family which presently comprises of 56 species, 27 biennials and 29 perennials [4]. Tagetes species and chemo-types from its genus have been largely examined for biological active metabolites that can be used in industry and medicine [5]. Compounds that have antimicrobial activity in the Tagetes minuta plant are said to be accumulated in the organs of the plant and their essential oils have not only antimicrobial effect but also insecticidal properties [6]. Extracts from Tagetes minuta leaf flowers and stem extracted using methanol have shown to contain secondary metabolites including terpenes which are thought to be responsible for antibacterial activities [7]. The genus Aloe is common in Kenya; with about 60 taxa recognized [8]. Aloe species have antibacterial, antifungal, anticancer, antiviral and immunomodulatory properties [9]. Aloe secundiflora other synonyms are; Aloe floramaculata, Aloe engleri and Aloe marsabitensis [10]. Aloe secundiflora leaf components have been credited for antibacterial, antifungal and antiviral and antihelmintic medicinal properties [10]. Herbalists from the Lake Victoria region have traditionally used Aloe secundiflora to treat ailments including chest problems, polio, malaria and stomach ache [11]. Vernonieae is a tribe of about 1300 species of plant in the Asteraceae (compositae) family which mostly contains herbaceous plants [12]. Vernonia laisopus decoctions from the stems and leaves have been traditionally been used by herbalist in East Africa to treat, malaria, worms and gastrointestinal problems [11]. Its extracts have also been used in treating some of the sexually transmitted diseases in southern parts of Africa [13]. Bulbine is a genus of plants in the family xanthorrhoeaceae and sub family asphodeloideae and its members are well known for their medicinal value [14]. Bulbine plant has been used for medicinal purposes in the early stages of the eighteen century by Dutch and British settlers of South Africa in treating various ailments [15]. The leaves of the plant have been used in the treatment of wound thought to be infected with bacterial pathogens and it has shown antibacterial properties [16]. Some of the species of the plant found in South Africa have been used for blood cleansing, treatment of ringworms and gravel rush by some local communities such as the Xhosa [15]. A decoction of bulbs and roots of some of the species has been used in the treatment of some of the venereal diseases in women and stomach upsets [17]. Escherichia coli are normal flora in the body of human beings and they can be nonpathogenic, commensal or pathogenic [18]. When pathogenic they usually cause urinary tract infections, systematic infections and enteric infections [19]. The development of resistance by Escherichia coli due to increase in use of antimicrobial agents has led to the use of medicinal plants extracts against it [20]. Medicinal plant extracts have shown to have antimicrobial activity against enteropathogenic Escherichia coli found in food material [21]. This study aided in determining whether the plant extracts can be used as an effective antimicrobial agent against Escherichia coli.

\section{Materials \& Methods}

\section{Plant material collection}

The fresh plant material of Aloe secundiflora, Bulbine frutescens, Vernonia lasiopus and Tagetes minuta were collected at Kenyatta University Arboretum. Voucher specimens were prepared and 
Page 2 of 4

deposited in the university herbarium in Plant Sciences Department for future reference. The plants were brought to the laboratory and thoroughly washed in running water to remove debris and dust particles and then rinsed using distilled water and finally air dried.

\section{Plant extract preparation}

The air dried plant materials were grinded into powder and soaked in methanol for 72 hours while placed in a Gallenkamp shaker at 65 revolutions per minute. Thereafter, the contents were homogenized and filtered using Whattman filter paper no. 1. The filtrate was poured into a round bottom flask and concentrated using a vacuum evaporator and stored in a labelled amber glass bottle at room temperature away from light and heat before being used for antibacterial efficacy test.

\section{Antimicrobial evaluation}

The microorganism used was clinical isolate of Escherichia coli obtained from Kenyatta University Health Centre Laboratory, Nairobi. It was tested against methanolic leaf extracts of Tagetes minuta, Aloe secundiflora, Bulbine frutescens and Vernonia lasiopus. Escherichia coli inoculum was concentrated by comparing it with a 0.5 McFarland standard. Discs of 6 milliliters were prepared from Whattman no.1 filter paper. The discs were sterilized by autoclaving. After sterilization the moisture discs were dried on hot air oven at $50^{\circ} \mathrm{C}$ [22]. The various solvent extracts discs prepared were impregnated with the extracts from $1000 \mathrm{mg} / \mathrm{ml}$ [23]. The antibacterial efficacy test was carried out using disc diffusion method [24]. Muller Hinton agar was used in the spread plate technique where the clinical isolate of Escherichia coli was spread using sterilized cotton wool swabs and exposed to extracts impregnated discs in milligrams per microliter from Aloe secundiflora, Tagetes minuta, Vernonia lasiopus and Bulbine frutescens. The discs were placed with equal distance between them on agar plates inoculated with Escherichia coli. Positive control discs used contained ciprofloxacin while negative control discs were impregnated with distilled water and dimethyl sulphoxide. The Petri dishes were incubated at $37^{\circ} \mathrm{C}$ for 24 hours. Zones of inhibition were measured in millimetres and their average determined. The experiment was carried in duplicates and the diameter of zones of inhibition formed measured. Minimal inhibitory concentration (MIC) was evaluated using the microplate method [25]. $100 \mu \mathrm{l}$ of $250 \mathrm{mg} / \mathrm{ml}$ of methanol extract was added to $100 \mu \mathrm{l}$ of sterile bacteriological peptone in the first well of the 96 well microplate and mixed well with a micropipette. $100 \mu \mathrm{l}$ of this dilution was transferred subsequently to wells two folding each dilution of the original extract. This was done to the extracts of Aloe secundiflora, Bulbine frutescens, Vernonia lasiopus, and Tagetes minuta. An inoculum of $100 \mu \mathrm{l}(0.5 \mathrm{McFarland}$ standard) of overnight clinical culture of Escherichia coli was added in each of the wells. Triplicate of each micro plate were made and the procedure repeated for the test organism. The plates were then incubated at $37^{\circ} \mathrm{C}$ for 24 hours. After incubation $40 \mathrm{~g} / \mu \mathrm{l}$ of $0.2 \mathrm{mg} / \mu \mathrm{l}$ of INT was added in each of the wells and the plates examined after an additional sixty minutes of incubation. Growth was indicated by a red colour (conversion of INT to formazan). The lowest concentration at which the colour was apparently invisible as compared to the next dilution was taken as the minimum inhibitory concentration [26]. Minimum bactericidal concentration (MBC) was determined by taking $100 \mu \mathrm{l}$ of suspension from micro plate wells that demonstrated no growth and inoculated on agar plates. The plates were incubated at $37^{\circ} \mathrm{C}$ for 24 hours. In the case where there was no bacterial growth with the value greater than minimum inhibitory concentration the concentration was used as the maximum bacterial concentration [26].

\section{Phytochemical analysis}

Presence of saponins, tannins, flavonoids and alkaloids in the crude extract were determined [27]

Tannins: Each of the extracts was weighed to $5 \mathrm{mg}$ and dissolved in $1 \mathrm{ml}$ of distilled water. Filtration was carried out after $2 \mathrm{ml}$ of $\mathrm{FeCl}_{3}$ was added. If there was presence of a blue or black precipitate then it indicated the presence of tannins [27].

Flavonoids: Each of the extracts was weighed to $5 \mathrm{mg}$ and dissolved in $1 \mathrm{ml}$ of ethanol and filtered. $2 \mathrm{ml}$ of $1 \% \mathrm{HCl}$ and magnesium ribbon was added to the filtrate. If there was formation of a pink or red colour it indicated the presence flavonoids [27].

Alkaloids: Each of the extracts was weighed to $5 \mathrm{mg}$ and dissolved in $2 \mathrm{ml}$ of methanol and filtered. 1\% HCL was added to the filtrate and the solution heated. Mayor's reagent was added drop wise and if there was formation of any colored precipitate it indicated the presence of alkaloids [27].

Saponins: Each of the extracts was weighed to $5 \mathrm{mg}$ and dissolved in $2 \mathrm{ml}$ of methanol and filtered. Distilled water was added and shaking done for a few minutes. If there was persistence frothing then it indicated the presence of saponins [27].

\section{Results}

All the plants extracts showed a considerable antibacterial activity against Escherichia coli. The antibacterial activity of the extracts greatly varied on the Muller Hinton agar plates. The plant extract from Tagetes minuta was more active in low concentrations against Escherichia coli as compared to the other extracts. The standard antibiotic used as positive control (ciprofloxacin) produced significantly sized zones of inhibition $(20 \pm 0.97 \mathrm{~mm})$. The negative control (Distilled water and Dimethyl sulphoxide) did not produce any zone of inhibition. The antimicrobial activity of the plant extracts against Escherichia coli was significant P (0.001) showing that the extracts had different pronounced antibacterial activity against Escherichia coli (Table 1).

\begin{tabular}{|l|l|l|l|}
\hline Plant extracts & MIC $(\mathbf{m g} / \mathbf{m l})$ & MBC $(\mathbf{m g} / \mathbf{m l})$ & $\begin{array}{l}\text { Zone of Inhibition } \\
(\mathbf{m m})\end{array}$ \\
\hline Tagetes minuta & 8.7 & 10.0 & $16 \pm 1.27$ \\
\hline Aloe secundiflora & 9.1 & 10.4 & $17 \pm 1.38$ \\
\hline Bulbine frutescens & 12.5 & 14.0 & $13 \pm 0.97$ \\
\hline Vernonia lasiopus & 10.0 & 11.5 & $12 \pm 1.67$ \\
\hline Ciprofloxacin & 0.00 & 0.00 & $20 \pm 3.11$ \\
\hline Dimethyl sulphoxide & 0.00 & 0.00 & $0 \pm 0.00$ \\
\hline Distilled water & 0.00 & 0.00 & $0 \pm 0.00$ \\
\hline Ker & & & \\
\hline
\end{tabular}

Key: \pm Standard error; MIC: Minimum inhibitory concentration; MBC: Minimum bactericidal concentration.

Table 1: Antimicrobial activity of plant extracts. 
The plant leaf extracts from Tagetes minuta, Aloe secundiflora Bulbine frutescens and Vernonia lasiopus when evaluated for the presence of phytochemicals shown in Table 2.

\begin{tabular}{|l|l|l|l|l|}
\hline Plant extracts & Saponins & Tannins & Alkaloids & Flavonoids \\
\hline Aloe secundiflora & + & + & + & + \\
\hline Vernonia lasiopus & + & + & + & + \\
\hline Bulbine frutescens & + & + & + & + \\
\hline Tagetes minuta & + & + & + & + \\
\hline Key: $(+)$ present & \multicolumn{3}{|l}{} \\
\hline
\end{tabular}

Table 2: Phytochemicals.

\section{Discussion}

Enteric bacterial pathogens are disease causing microorganisms that are usually located in the intestinal tracts of either animals or human beings. They belong to the family Enterobacteriaceae which is a large family of Gram-negative bacteria along with many harmless symbionts. The pathogenic members are usually associated with infections that are characterized by enteric fevers, abdominal pain and diarrhoea and vomiting.

Escherichia coli is a gram negative facultative anaerobic enteric bacteria that is commonly found in the lower intestinal tract of endotherms. They are normal flora of the gut and they benefit host by producing vitamin $\mathrm{K} 2$. However, some of the serotypes of the bacteria have been known to be cause diseases with the worst the being a bloody diarrhoea that can lead also to kidney failure in children and immunocompromised individuals. There has been emergence of antibiotic resistant strains of Escherichia coli hence need of finding new resources for the manufacture of antibiotics [28]. Medicinal plants have been used to produce herbal drugs that has been used from ancient times to treat various diseases and there antimicrobial properties make them a rich source of many potent drugs [2].

From the study carried out, the extracts from the four medicinal plants showed antimicrobial activity against Escherichia coli. Tagetes minuta was more active at low concentrations as compared to the other extracts. The extract from Tagetes minuta also had secondary metabolites alkaloids, saponins, tannins and flavonoids which have been known to contain antimicrobial activities. Secondary metabolites such as flavonoids have been found to contain antimicrobial activity against both Gram negative and Gram positive bacteria [29].

Aloe secundiflora also showed antimicrobial activity against Escherichia coli producing the largest average zone of inhibition against Escherichia coli (Table 1). Extracts from Aloe secundiflora have been found to contain antimicrobial activity due to the presence of secondary metabolites such as saponins and anthraquinones [30]. From the study the extract from Aloe secundiflora contained saponins, alkaloids, tannins and flavonoids which might be responsible for its antimicrobial activity against Escherichia coli.

Vernonia lasiopus and Bulbine frutescens also showed a pronounced level of antimicrobial activity against Escherichia coli. The extracts also contained the secondary metabolites as shown in Table 2. The extracts from Bulbine frutescens have been used in treating stomach upsets which may be due to food poisoning cause by enteric bacteria in Southern Africa [17]. The secondary metabolites from the
Bulbine frutescens might be responsible for its antimicrobial activity [31]. A decoction from its roots and bulbs has also been found to contain antimicrobial activity [31]. Vernonia lasiopus also showed antimicrobial activity against Escherichia coli but produced the smallest average zone as compared to other plant extracts. Aqueous extracts from the plant have shown antimicrobial activity against bacterial pathogens [32]. The presence of the secondary metabolites from the extracts also might be attributed to its antimicrobial activity.

\section{Conclusion}

This study has revealed extract from the medicinal plants can be used in treating diseases caused by some of the pathogenic serotypes of Escherichia coli. It further elucidated that secondary metabolites from medicinal plant parts might be responsible for the antibacterial activity of the plant extracts against Escherichia coli. Therefore, there is need for further evaluation of the purified bioactive components of the extracts that can be exploited as new potent raw materials for the manufacture of herbal drugs and antimicrobial agent's productions.

\section{References}

1. Shazadi I, Hassan A, Khan UW, Mohammad MS (2010) Evaluating biological activities of the seed extracts from Tagetes minuta $L$. found in Northern Pakistan. J Med Plant Res 4: 2108-2112.

2. Srivastava J, Lambert J, Vietmeyer N (2005) Medicinal plants: An expanding role in from Western India for potential antimicrobial activity. Indian. J Pharmacol 37: 406-409.

3. Mohanta B, Chakraborty A, Sudarshan M, Dutta RK, Baruah M (2003) Elemental profile in some common medicinal plants of India. Its correlation with traditional therapeutic usage. J Radio anal Nuc Chem 258: 175-179.

4. Soule JA (1993) Tagetes minuta: A Potential New Herb from South America: New Crops, Proceedings of the New Crops Conference. pp: 649-654.

5. Green MM, Singer JM, Sutherland DJ, Hibben CR (1991) Larvicidal activity of Tagetes minuta (marigold) toward Aedes aegypti. J Am Mosq Control Assoc 7: 282-286.

6. Piccaglia R, Marotti M, Pesenti M, Mattarelli P, Biavati B (1997) Chemical composition and antimicrobial activity of Tagetes erecta and Tagetes patula, in Essential Oils: Basic Appl Res pp: 49-51.

7. Lopez LM, Bonzani EN and Zygadlo JA (2008) Allelopathic potential of Tagetes minuta terpenes by a chemical, anatomical and phytotoxic approach. J Biochem System Ecol 36: 882-890.

8. Hendricks L, Wright N (1979) Diagnosis of cutaneous leishmaniasis by in vitro cultivation of saline aspirates in Schneider's Drosophila Medium. Am J Trop Med Hyg 28: 962-964.

9. Holzmuller P, Sereno D, Cavaleyra M, Mangot I, Daulouede S, et al. (2002) Nitric oxide-mediated proteasome-dependent oligonucleosomal DNA fragmentation in Leishmania amazonensis amastigotes. Infect Immun 70: 3727-3735.

10. Kaingu F, Kibor A, Waihenya R, Shivairo R, Mungai L (2013) Efficacy of Aloe secundiflora Crude Extracts on Ascaridia galli in vitro. S Agric Res.

11. Kigondu EV, Rukunga GM, Keriko JM, Tonui WK, Gathirwa JW, et al. (2009) Anti-parasitic activity and cytotoxicity of selected medicinal plants from Kenya. J Ethnopharmacol 123: 504-509.

12. Keeley SC, Forsman ZH, Chan R (2007) A phylogeny of the "evil tribe" (Vernonieae: Compositae) reveals Old/New World long distance dispersal: support from separate and combined congruent datasets (trnLF, ndhF, ITS). Mol Phylogenet Evol 44: 89-103.

13. Kambizi L, Afolayan AJ (2001) An ethnobotanical study of plants used for the treatment of sexually transmitted diseases (njovhera) in Guruve District, Zimbabwe. J Ethnopharmacol 77: 5-9. 
Citation: Opinde HR, Gatheri GW, Nyamache AK (2016) Antimicrobial Evaluation of Crude Methanolic Leaf Extracts from Selected Medicinal Plants Against Escherichia coli. J Bacteriol Parasitol 7: 272. doi:10.4172/2155-9597.1000272

Page 4 of 4

14. Acock JPH (1975) Veld types of South Africa. Memoirs of Botanical Survey of South Africa Botanical Research Institute. Pretoria, Department of Agriculture and Water Supply, pp: 57.

15. Coopoosamy RM, Magwa ML, Mayekiso B (2000) Proceedings: Science and Society University of Fort Hare, Bhisho, Eastern Cape, South Africa.

16. Kelmanson JE, Jäger AK, van Staden J (2000) Zulu medicinal plants with antibacterial activity. J Ethnopharmacol 69: 241-246.

17. van Wyk BE (2008) A broad review of commercially important southern African medicinal plants. J Ethnopharmacol 119: 342-355.

18. Kaper JB, Nataro JP, Mobley HL (2004) Pathogenic Escherichia coli. Nat Rev Microbiol 2: 123-140.

19. Mandel MJ, Silhavy TJ (2005) Starvation for different nutrients in Escherichia coli results in differential modulation of RpoS levels and stability. J Bacteriol 187: 434-442.

20. Akram M, Shahid M, Khan AU (2007) Etiology and antibiotic resistance patterns of community-acquired urinary tract infections in $\mathrm{J} \mathrm{N} \mathrm{M} \mathrm{C}$ Hospital Aligarh, India. Ann Clin Microbiol Antimicrob 6: 4.

21. Fullerton M, Khatiwada J, Johnson JU, Davis S, Williams LL (2011) Determination of antimicrobial activity of sorrel (Hibiscus sabdariffa) on Escherichia coli O157:H7 isolated from food, veterinary, and clinical samples. J Med Food 14: 950-956.

22. Arunkumar S, Muthuselvam M (2009) Analysis of phytochemical constituents and antimicrobial activities of Aloe vera L. against clinical pathogens. J Agric Sci 5: 572-576.

23. Mbanga J, Mangoma N, Saidi B (2010) An evaluation of the antimicrobial activities of Aloe barberdensis, A. chabaudii and A. arborescens leaf extracts used in folk fore veterinary medicine in Zimbabwe. J Anl Vet advan 9: 2918-2923.
24. Newall CA, Anderson LA, Phillipson JD (1996) Herbal medicines. The pharmaceutical Press London, pp: 25.

25. Eloff JN (1998) A sensitive and quick microplate method to determine the minimal inhibitory concentration of plant extracts for bacteria. Planta Med 64: 711-713.

26. Rabe T, Mullholland D, van Staden J (2002) Isolation and identification of antibacterial compounds from Vernonia colorata leaves. J Ethnopharmacol 80: 91-94.

27. Congesta WTC (2005) Preliminary screening of some folklore medicinal plants from Preliminary screening of some folklore medicinal plants from Western India for potential antimicrobial activity Eastern India for potential antimicrobial activity. Indian J Pharmacol 37: 408-409.

28. Maynard C, Fairbrother JM, Bekal S, Sanschagrin F, Levesque RC, et al. (2003) Antimicrobial resistance genes in enterotoxigenic Escherichia coli O149:K91 isolates obtained over a 23-year period from pigs. Antimicrob Agents Chemother 47: 3214-3221.

29. Tereschuk ML, Riera MV, Castro GR, Abdala LR (1997) Antimicrobial activity of flavonoids from leaves of Tagetes minuta. J Ethnopharmacol 56: 227-232.

30. Garcia SK, Villarreal AN, Lubben P, Pena RLM (2006) Chrysophanol, an antimicrobial anthraquinone from the root extract of Colubrina greggii. J Mex Chem Soc 50: 76-78.

31. Coopoosamy RM (2011) Traditional information and antibacterial activity of four Bulbine species (Wolf). Afri J Biotech 10: 220-224.

32. Kareru PG, Gachanja AN, Keriko JM, Kenji GM (2007) Antimicrobial activity of some medicinal plants used by herbalists in Eastern province, Kenya. Afr J Tradit Complement Altern Med 5: 51-55. 